\title{
Does a One-Size-Fits-All Cost-Sharing Approach Incentivize Appropriate Medication Use? A Roundtable on the Fairness and Ethics Associated with Variable Cost Sharing
}

\author{
Jennifer S. Graff, PharmD; Chuck Shih, PhD; Thomas Barker, JD; Gabriela Dieguez, FSA, MAAA; \\ Cheryl Larson, BA; Helen Sherman, PharmD; and Robert W. Dubois, MD, PhD
}

\begin{abstract}
BACKGROUND: Tiered formularies, in which patients pay copays or coinsurance out-of-pocket (0OP), are used to manage costs and encourage more efficient health care resource use. Formulary tiers are typically based on the cost of treatment rather than the medical appropriateness for the patient. Cost sharing may have unintended consequences on treatment adherence and health outcomes. Use of higher-cost, higher-tier medications can be due to a variety of factors, including unsuccessful treatment because of lack of efficacy or side effects, patient clinical or genetic characteristics, patient preferences to avoid potential side effects, or patient preferences based on the route of administration. For example, patients with rheumatoid arthritis may be required to fail low-cost generic treatments before obtaining coverage for a higher-tier tumor necrosis factor alpha inhibitor for which they would have a larger financial burden. Little is known about stakeholders' views on the acceptability of greater patient cost sharing if the individual patient characteristics lead to the higher-cost treatments.
\end{abstract}

OBJECTIVE: To identify and discuss the trade-offs associated with variable cost sharing in pharmacy benefits.

METHODS: To discuss the trade-offs associated with variable cost sharing in pharmacy benefits, we convened an expert roundtable of patient, payer, and employer representatives (panelists). Panelists reviewed background white papers, including an ethics framework; actuarial analysis; legal review; and stakeholder perspectives representing health plan, employer, and patient views. Using case studies, panelists were asked to consider (a) when it would be more (or less) acceptable to require higher cost sharing; (b) the optimal distribution of financial burdens across patients, all plan members, and employers; and (c) the existing barriers and potential solutions to align 00P costs with medically appropriate treatments.

RESULTS: Panelists felt it was least acceptable for patients to have greater 00P costs if the use of the higher-cost treatment was due to biological reasons such as step therapy $(6=$ unacceptable, $9=$ neutral, $2=$ acceptable) or diagnostic results ( $5=$ unacceptable, $10=$ neutral, and $2=$ acceptable). In contrast, panelists felt it was more acceptable for patients to pay greater OOP costs when treatment choice was based on preferences to avoid a side-effect risk ( 1 = unacceptable, $3=$ neutral, and $13=$ acceptable) or the route/frequency of administration ( $1=$ unacceptable, $1=$ neutral, and $15=$ acceptable). Five guiding principles emerged from the discussion: When patients have tried lower-cost therapies unsuccessfully, the benefits of higher-cost treatments were certain and significant, the cost difference between treatments was aligned with improved benefits, and penalties due to bad luck were mitigated, then cost-sharing differences should be minimized but not eliminated.

CONCLUSIONS: Patient OOP costs can affect the use of both inappropriate and appropriate medications. This study identified 5 guiding principles to determine when it was more (or less) acceptable for patients with the same or similar conditions to have different 00P costs. Barriers that hinder the alignment of care and patient cost sharing exist. Policies that facilitate the alignment of patient cost sharing with appropriate care are needed.

J Manag Care Spec Pharm. 2017;23(6):621-27

Copyright $\odot 2017$, Academy of Managed Care Pharmacy. All rights reserved.

\section{What is already known about this subject}

Tiered formularies, in which patients pay copays or coinsurance out-of-pocket (OOP), are used to manage costs and encourage more efficient use of health care resources.

As patients with the same or similar condition may need alternative treatments because of their genetic characteristics, comorbidities, or disease severity, they may need medications on different formulary tiers and have different OOP expenses.

Cost sharing is typically based on treatment cost and formulary tier rather than the medical appropriateness for patients. Greater cost sharing may have both intended and unintended consequences on treatment adherence, costs, and health outcomes.

\section{What this study adds}

This study used a case study approach and stakeholder panel to assess when it was more (or less) acceptable to require patients with the same or similar condition to have variable OOP expenses.

Five guiding principles were identified when variable cost sharing was less acceptable for patients who require higher-tier, highercost formulary medications.

The proposed solutions and discussion can help clarify and prioritize the trade-offs between who benefits and who pays for prescription medications.

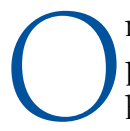
$\mathrm{n}$ account of limited financial resources, employers and payers must determine how to manage and distribute health care benefits and costs. To encourage more informed and efficient treatment choices, tiered formularies, in which patients pay copays or coinsurance out-of-pocket (OOP) based on the formulary tier, are commonly used. Initially used as a tool to incentivize patients' use of generic medications, additional formulary tiers were added and the difference in OOP cost sharing between tiers was widened.

In 2015, patient cost sharing among employer-sponsored plans varied widely based on tiers $(\$ 11, \$ 57, \$ 102$, and 17\%$37 \%$ for generic medications, tier 3 , tier 4 , and specialty medications, respectively). ${ }^{1}$ Because cost sharing is calculated based on tier placement rather than medical appropriateness, 
OOP expenses can vary for patients with the same or similar condition. For example, 2 groups of patients with rheumatoid arthritis (RA) may have different OOP costs if 1 group is adequately treated with generic methotrexate while the other group requires a more costly biologic therapy. However, this other group will have higher OOP expenses and greater cost sharing due to the medication tier placement.

Because not all treatments work the same for all patients, patients may require alternative medications due to their genetic characteristics, comorbidities, or disease severity. Other patients may prefer alternative therapies due to the anticipated side effects or the medication administration route or frequency. For these patients, alternative treatments may have higher OOP cost sharing. As multiple studies have demonstrated, higher OOP costs are associated with reduced initiation of and persistence with both inappropriate and appropriate medications and may have unintended health consequences..$^{2-4}$

When lower-cost alternatives provide equal or greater benefits to higher-cost treatments, higher cost sharing to encourage appropriate treatment is straightforward. However, when higher-cost, higher-tier medications provide greater benefits, incentivizing appropriate treatments through patient cost sharing is less clear. Higher-cost, higher-tier medications can benefit individual patients. Yet shifts in health care spending can affect the ability of employers to offer health benefits, members to pay premium contributions, and individual patients to afford the associated copay or coinsurance. Determining the optimal distribution of costs associated with higher-cost medications requires trade-offs between who benefits and who pays. These trade-offs between benefits and costs can be clarified and prioritized through clearly defined distributive justice principles. ${ }^{5}$

This article examines whether a one-size-fits-all approach incentivizes appropriate medication use. To ground the discussion, we sought stakeholder perspectives on 3 questions: (1) When is it acceptable to have variable OOP expenses for patients with the same or similar condition? (2) For case studies in which minimizing cost differences between patients with the same or similar condition is acceptable, what is the optimal approach to distribute increased costs? (3) What are the barriers and solutions needed to align patient OOP costs with medically appropriate patient care?

\section{Methods}

To understand when widely different OOP cost sharing was acceptable for patients with the same or similar condition, we first identified 4 exemplary case studies (Figure 1). These case studies assumed that the higher-cost treatments were the best clinical option based on (a) prior failure with step therapy, (b) results of a diagnostic test, (c) patient preference for potential side-effect risks, or (d) patient preference for a particular route or frequency of administration. We then identified specific clinical examples as case studies to foster discussion and ascertain the contextual factors of importance. To simplify the discussions, we assumed there was sufficient evidence demonstrating the medical appropriateness of the higher-cost treatments. Each case study is described here and in the Appendix (available in online article).

\section{Case Studies}

Step Therapy (Rheumatoid Arthritis). First, we considered a case study in which step therapy is used to guide patient care. For example, treatment guidelines for patients with nonaggressive RA recommend initiating treatment with methotrexate before trying combination oral disease-modifying antirheumatic drugs (DMARDs) or subsequently, specialty medications (e.g., anti-tumor necrosis factor, T-cell, or B-cell treatments). Because only some patients benefit from the lower-cost methotrexate or combination DMARDs, other patients with RA may require higher-cost, higher-copay specialty medications.

Diagnostic Testing (Cystic Fibrosis). Second, we contemplated a case study in which a valid diagnostic test indicates that a higher-cost treatment is a better choice than standard therapy. For patients with cystic fibrosis (CF) and the G551D mutation, studies show that ivacaftor improves outcomes compared with usual treatment, but at a higher cost and patient OOP expense than alternatives.

Patient Preference for Side-Effect Tolerability (Fibromyalgia). Third, we evaluated a case study in which patients prefer 1 medication to alternative treatments due to the potential risk of side effects. For example, generic duloxetine is associated with greater risk of headaches, nausea, and diarrhea than pregabalin. Patients who prefer to avoid these side effects and use pregabalin pay higher OOP costs than patients who use generic duloxetine.

Patient Preference for Route/Frequency of Administration (Osteoporosis). Finally, we considered a case study in which patients prefer a treatment due to the frequency or mode of administration. For patients with osteoporosis, biannual subcutaneous treatment with denosumab may be preferable to daily, weekly, or monthly oral bisphosphonates. Denosumab, typically on the specialty tier, has a higher cost and patient OOP expense than oral bisphosphonates, usually on the generic tier.

\section{Premeeting White Papers}

Next, we explored the acceptability of variable cost sharing for patients with the same or similar condition and the optimal distribution of costs. Experts in their respective fields developed an ethics framework, assessed actuarial impacts, and conducted a legal review. Because costs can affect multiple stakeholders, stakeholders representing patient, employer, and health plan communities each developed a white paper (available upon request). 


\section{FIGURE 1 Illustrative Flow Diagram of Methods Used to Assess Acceptability of Variable Cost Sharing}

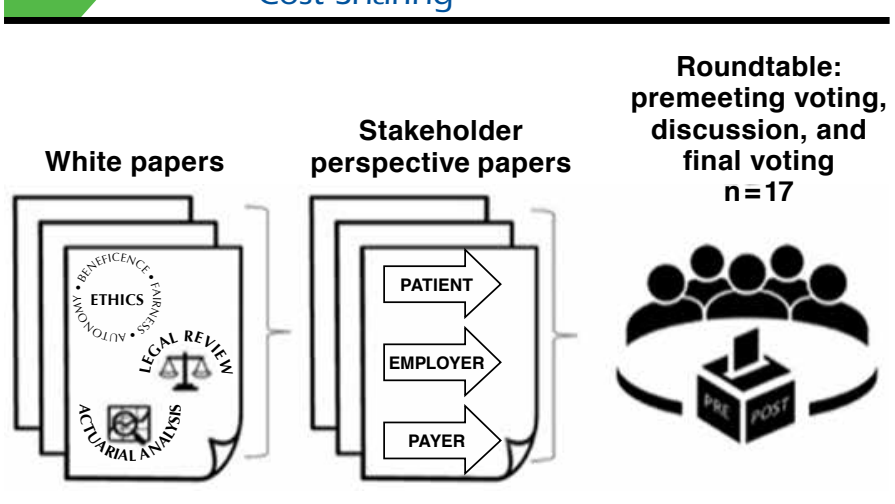

Note: Four case studies and clinical examples were examined: step therapy (rheumatoid arthritis), diagnostic testing (cystic fibrosis), patient preference for side effects (fibromyalgia), and patient preference for route/frequency of administration (osteoporosis).

\section{Roundtable}

A roundtable to broaden the dialogue was convened with stakeholders from the payer, employer, and patient community who had previous work addressing benefit design and pharmaceutical coverage policies. Thirty-six individuals from payers, employers or employer groups, patient groups, and consulting or academic organizations were invited to participate in the roundtable; 17 individuals participated $(n=6$, 3,2 , and 6 , respectively). Prior to the meeting, convened in Washington, DC, on February 5, 2015, the 6 white papers were provided, and panelists completed an online questionnaire rating the acceptability of higher OOP expenses using a 9-point Likert scale ( 1 = very unacceptable, 9 = very acceptable) for each of the 4 case studies.

Telephone interviews with panelists were held to understand the factors driving their acceptability ratings. Premeeting ratings, trichotomized into 3 categories of acceptability (1-3= unacceptable, 4-6=neutral, 7-9=acceptable), were presented at the stakeholder meeting and discussed prior to the final round of voting. Premeeting voting results are not presented in this report. Individual factors from the case studies (e.g., the cost difference between treatment alternatives) were subsequently altered to delineate when the use of variable OOP cost sharing changed from acceptable to unacceptable.

On the basis of the roundtable discussion, panelists were asked to react to an additional case study based on the principles that emerged. In this scenario, we assumed the clinical condition has a substantial impact on a patient's quality of life. After an unsuccessful trial of the recommended initial treatment, an alternative treatment has a significant chance of improved health outcomes. These benefits are proportional to the increased treatment costs compared with the initial treatment.
For cases in which variable OOP costs were deemed less acceptable, panelists discussed different benefit approaches to offset reduced revenues from lower cost sharing and increased use of higher-cost treatments. The roundtable discussed 3 approaches: (1) raising premiums for all members, (2) spreading costs across all patients receiving any medication, and (3) spreading costs across patients with the particular condition. Finally, panelists described barriers that exist and need to be resolved to align OOP costs with medically appropriate treatments. The roundtable discussion was thematically reviewed and is summarized in the next section.

\section{Results}

Roundtable panelists discussed the 4 case studies and rated the acceptability of different OOP costs for patients with the same or similar condition (Figure 2). Case studies in which patients pay more OOP costs due to biological reasons (e.g., genetic or disease-related characteristics) were rated the least acceptable. For the step therapy case study, 6 of the 17 panelists believed that higher OOP costs were unacceptable for patients for whom initial treatment with a DMARD was ineffective. Nine panelists were neutral, and 2 believed it was acceptable for these patients to pay more. For the diagnostic testing case study, 5 panelists voted that higher OOP cost sharing for patients with the G551D mutation was unacceptable, 10 were neutral, and 2 concluded that higher cost sharing was acceptable. In contrast, only 1 panelist felt it was unacceptable for patients to pay more OOP costs when the use of higher-tier medications was due to patient preferences.

In the roundtable discussion, contextual factors of importance were identified. The following sections detail the 5 guiding principles that emerged related to when higher OOP costs were less acceptable and how best to balance costs among individual patients, plan members, and employers when individual patients require higher-cost treatments.

\section{"Try and Fail" Is Important}

Information on which treatments work for which patients was often lacking. When evidence existed that 1 treatment was superior, panelists emphasized the importance of beginning or trying lower-cost treatments. For example, most panelists believed that it was acceptable for patients diagnosed with moderate RA to begin treatment with methotrexate before initiating more costly alternatives. Similarly, panelists felt it was acceptable to incentivize the lower-cost fibromyalgia treatment because side effects affect only a proportion of patients. If the initial treatment was ineffective or resulted in actual side effects, there was more agreement among the panel that these patients should have access to the higher-cost therapy at a lower OOP cost, a strategy known as "reward the good soldier.",

If a priori evidence (e.g., based on a validated diagnostic test or other clinical characteristic) existed that individual patients 
Step Therapy-Rheumatoid Arthritis

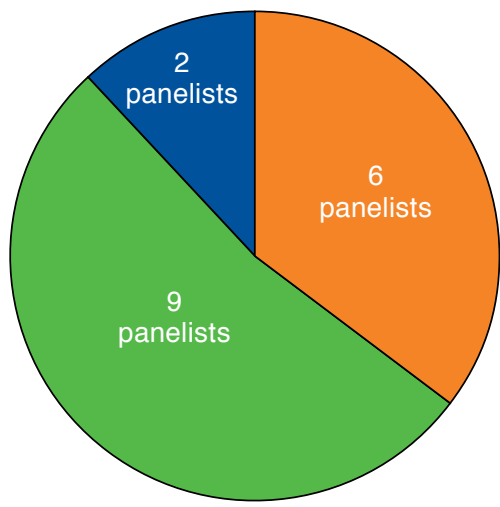

Diagnostic Testing-Cystic Fibrosis

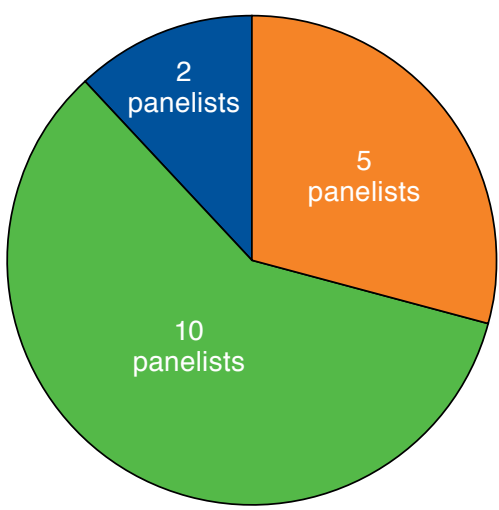

Preferences for Side-Effect Risks-Fibromyalgia

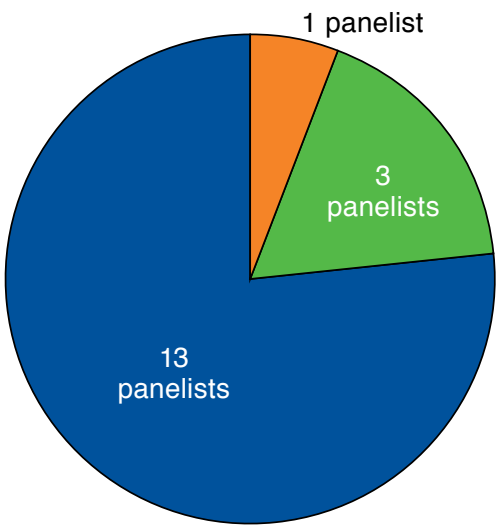

Preferences for Route/Frequency of AdministrationOsteoporosis

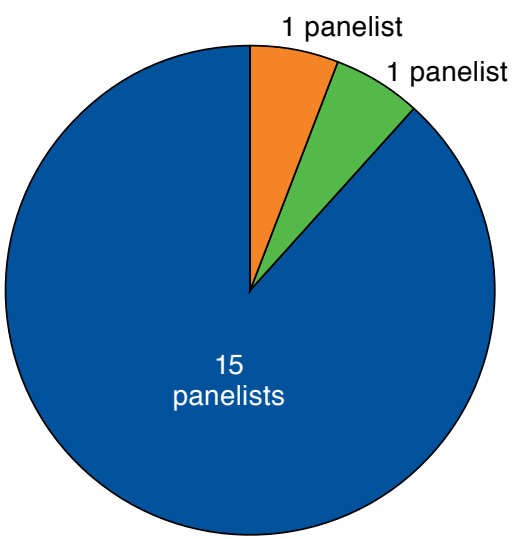

Acceptable (ratings 7-9 on Likert scale)

Neutral (ratings 4-6 on Likert scale)

Unacceptable (ratings 1-3 on Likert scale)

Note: Roundtable participants voted on this question: How acceptable are variable copays for each patient population?

benefit from (or will be harmed by) a treatment, then incentives to encourage the higher-cost treatments without trying the lower-cost treatment were acceptable. However, panelists sought objective rather than subjective measures of treatment failure (e.g., biomarkers rather than patient-reported compliance or symptoms).

\section{Benefits Should Be Certain and Significant}

Panelists found higher OOP costs were acceptable unless the higher-cost treatment had proven statistically significant and clinically meaningful benefits compared with treatment alternatives. For example, 1 panelist desired larger treatment benefits in the RA case study (e.g., a $70 \%$ rather than a $20 \%$ improvement in American College of Rheumatology scores). Panelists wanted information on functional outcomes rather than surrogate outcomes in the CF case study (e.g., exacerbations or infections rather than FEV1). Panelists believed it was more appropriate to lower patient OOP costs for the higher-cost treatment when the health benefits were significant, meaningful, and certain.

\section{Costs Must Align with Benefits}

Panelists emphasized the balance of total health care costs against the treatment benefits and harms. In the osteoporosis example, the increased medication costs were considered insufficient when weighed against the reductions in noncompliance, bone fractures, and hospitalizations. If evidence demonstrated significant net health benefits, panelists believed that incentivizing treatment with higher-cost medications through reduced patient cost sharing was more acceptable. 


\section{Penalties Because of "Bad Luck," Not Preferences, Should Be Mitigated}

Higher OOP costs are associated with "bad luck" arising from factors beyond the patient's control. Some panelists expressed sympathy for patients paying more OOP based solely on their biology or genetics. Because CF is the result of genetic factors outside of a patient's control, some, but not all, panelists felt it was acceptable to reduce the cost-sharing differential for CF patients with the G551D mutation. In similar case studies, panelists wanted to know with certainty that the diagnostic test or clinical characteristics could predict a treatment's efficacy.

In contrast, higher variable OOP cost sharing was most acceptable when patients preferred a higher-cost treatment due to the potential side effects or the route or frequency of administration. For example, most panelists agreed higher cost sharing was appropriate for therapies based on convenience (e.g., biweekly administration instead of daily oral use). Similarly, some panelists recommended that when preferences were cited as the rationale for more costly treatments, individual patients rather than all plan members or employers should be responsible for the increased costs. However, panelists recognized that preferences may affect patient goals (e.g., quality of life vs. survival); outcomes (e.g., preferences for treatment benefits and risks); and treatment adherence. Panelists were most likely to consider preferences if there was sufficient evidence that the patient preferences affect health outcomes.

\section{Differences in 00P Should Be Lowered but Not Eliminated}

When evidence was sufficient to support the use of the higher-cost option, panelists recommended lowering, but not eliminating, the OOP cost difference. Reduced cost sharing at a tier 2 or 3 level, as opposed to a tier 1 level, was preferred. Some panelists wanted to decrease patient cost sharing proportional to the medical cost offsets but recognized the logistical difficulty. Panelists believed lower, but not eliminated, OOP cost-sharing differences were needed to incentivize patients and providers to start with lower-cost, lower-tier treatments.

In the concluding case study, which reflected the 5 guiding principles, nearly all panelists believed that higher cost sharing for the higher-cost, alternative treatment was unacceptable.

\section{Discussion}

Cost sharing based on formulary tier rather than medical appropriateness may have both intended and unintended effects on patient outcomes. This study identified 5 guiding principles in which it was more (or less) acceptable to require higher cost sharing. However, roundtable panelists identified practical barriers that need to be overcome to align patient OOP costs with appropriate care. Policies and solutions that increase the availability of evidence, facilitate the link between benefits and value, balance the distribution of costs, increase patient consumerism, and avoid unintended consequences are needed. The proposed solutions to the identified barriers are described in the following sections.

\section{Ensure Evidence Is Available About Which Treatments Work for Which Patients}

Without adequate evidence, determining the clinical benefits of 1 treatment compared with alternative treatments was difficult. Studies that assess treatment effectiveness among subpopulations of patients on payer-relevant outcomes are needed. Research underway by the Patient-Centered Outcomes Research Institute to inform decision making, by the Office of the National Coordinator for Health Information Technology to improve health information technology, and by multistakeholder collaboratives to analyze stakeholder-relevant questions can increase the availability of real-time information about which treatments work for which patients.

\section{Facilitate the Linkage of Benefits and Appropriate Care}

Clinically appropriate care requires translation to incentivize care in benefit designs. Some organizations account for patientspecific needs (e.g., genetic characteristics such as in the CF case) through formulary exceptions in a case-by-case manner. However, this approach is labor-intensive for patients, providers, and payers. Member-wide initiatives, such as value-based insurance design and the Maine Health Coalition, systematically lower OOP costs for high-value services, raise OOP costs for low-value services, and reduce patient cost sharing if certain criteria are met.

Clinically nuanced benefit design requires information to link value to individual patients. This clinically nuanced approach links cost sharing to patient characteristics (e.g., patient test results, diagnosis, or medication history) rather than to medication National Drug Codes. Linkages between medical and pharmacy networks, adoption of electronic prior authorization, and more sophisticated pharmacy network algorithms to determine copays or coinsurance at the point of sale can align medically appropriate treatments with patient cost sharing.

In addition to health information infrastructure, streamlined processes to review and apply benefit changes are needed. Health plans are required to update plan documents describing benefits (e.g., summary plan description, summary of material modifications, and summary of benefits and coverage) with each of the relevant oversight agencies. Because some benefits are offered in several states and have multiple oversight bodies, more sophisticated designs (e.g., cost sharing based on clinical history) can result in considerable administrative burden. Greater awareness of these approaches and a coordinated approach across oversight bodies can reduce the logistical barriers. 


\section{Increase Consumerism and Member Communication}

Incentivizing patients to use medically appropriate treatments requires engaging plan members as active rather than passive consumers of health care. Active consumers need awareness of which treatments are lower and higher value. Consumers also need to understand how and when different treatment changes result in different OOP costs. Many health plans and employers are investing in communication tools to improve member understanding of the benefits offered, awareness of health care costs, and appreciation of how costs are distributed between the employer and the member.

\section{Balance Effect of Cost-Sharing, Premium, and Deductible Changes}

The financial impact of increased costs due to higher-cost medication use and reduced cost-sharing revenues can be offset. We discussed 3 opportunities: (1) increasing premium contributions or deductibles for all plan members, (2) raising lower-tier cost sharing for all medications, or (3) spreading cost sharing for lower-tier medications across patients with the particular condition.

The panel highlighted the trade-offs associated with each approach. For example, premium contributions and deductibles affect the affordability of insurance for employees and their families, and increased member contributions can affect an employer's ability to recruit and retain talent. Some employers or plans may be able to absorb higher-cost medically appropriate care, but others may be unable to do so and remain competitive. Health plans are hesitant to be the first plan to lower patient cost sharing for particular conditions due to adverse member selection, whereby sicker members choose plans with richer benefits and healthy patients choose lowercost, lower-premium plans.

Finally, cost sharing has been shown to alter patient decisions to seek care and adhere to therapy and may result in preventable and more expensive care (e.g., hospitalization and emergency room visits). For these reasons, panelists believed a blended, rather than a singular, approach to distributing costs was needed.

\section{Avoid Unintended Consequences}

Unintended consequences for patients, employers, and plans due to benefit changes should be avoided. To reduce the OOP impact to patients, some states (e.g., New York) have limited the use of specialty tiers or have implemented caps on OOP expenditures (e.g., limiting the cost difference between the lowest and highest tiers to $<500 \%$ ). OOP maximums in commercial plans minimize "bad luck" for members with higher costs. Other approaches have been proposed to raise the $\$ 600$ per month Medicare Part D specialty-tier threshold. This approach would reduce the number of medications eligible for the specialty tier and therefore reduce the patient OOP costs.
Similarly, employers and health plans are at risk if sicker employees choose employers or plans with richer benefits. For small businesses, pooling risk through the small business exchanges may reduce unintended consequences. For health plans, risk adjusters can mitigate adverse selection issues while allowing plans to remain competitive.

\section{Limitations}

Our study has a number of limitations. First, we limited our discussion to simplified case studies to isolate individual factors related to the acceptability of variable cost sharing. In the real world, infinite permutations of these factors exist (e.g., the prevalence of the condition, the clinical significance of the condition, availability of treatment alternatives, and potential cost offsets). Second, we tested these case studies with 17 experts; our conclusions may have changed with a different mix of roundtable panelists. Third, we focused on employersponsored commercial plans and did not include Medicaid or state health exchanges. Medicaid copay limits and state exchange OOP maximums limit patient costs, thus eliminating the cost differentials for both appropriate and inappropriate medication use.

Finally, our efforts considered the acceptability of variable OOP costs in the form of cost sharing, member premiums, and deductibles. Market-based solutions such as risk-sharing agreements, indication-based pricing, and pay-for-performance initiatives were not discussed. Other cost-containment strategies (e.g., state-specific cost-sharing limits and rebates) were beyond the scope of this project and required a different set of background materials.

\section{Conclusions}

Tiered formularies and corresponding tiered patient copay or coinsurance requirements are 1 approach to manage costs and incentivize the use of appropriate care. However, increasing patients' OOP costs can affect the use of both inappropriate and appropriate medications. A stakeholder roundtable identified 5 guiding principles to determine when it was more (or less) acceptable to have different OOP costs for patients with the same or similar conditions. In case studies in which prior treatments were tried unsuccessfully, the benefits of the highercost treatments were certain and significant, the cost differences between treatments were aligned with improved health benefits, and penalties due to "bad luck," not preferences, were mitigated, then panelists believed that OOP costs should be lowered but not eliminated.

Barriers that hinder the alignment of care and patient cost sharing exist. Solutions that improve the availability of evidence; facilitate the link between benefits and appropriate care; promote patient consumerism; balance cost sharing, premium, and deductible impacts; and avoid unintended consequences for patients, employees, and health plans can help. 
A one-size-fits-all cost-sharing approach may not incentivize appropriate medication use. Incorporating the guiding principles into benefit design and working toward the proposed solutions may incentivize appropriate care through patient cost sharing and improve the care received by patients.

\section{Authors}

JENNIFER S. GRAFF, PharmD; CHUCK SHIH, PhD; and ROBERT W. DUBOIS, MD, PhD, National Pharmaceutical Council, Washington, DC. THOMAS BARKER, JD, Foley Hoag, Washington, DC; GABRIELA DIEGUEZ, FSA, MAAA, Milliman, New York, New York; CHERYL LARSON, BA, Midwest Business Group on Health, Chicago, Illinois; and HELEN SHERMAN, PharmD, Solid Benefit Guidance, Portland, Oregon.

AUTHOR CORRESPONDENCE: Jennifer S. Graff, PharmD, Vice President, Comparative Effectiveness Research, National Pharmaceutical Council, 1717 Pennsylvania Ave., Ste. 800, Washington DC 20006. Tel.: 202.827.2083; E-mail: jgraff@npcnow.org.

\section{DISCLOSURES}

Funding for this roundtable was provided by the National Pharmaceutical Council (NPC). Graff and Dubois are employed by the NPC. Shih was employed by the NPC at the time of this study. Barker, Dieguez, Sherman, and Larson received consulting fees for participation in this study. Larson also reports receiving grants and other payment from multiple major pharmaceutical manufacturers outside of this study. The NPC employees developed the study design and chose the case studies in collaboration with the white paper authors. The roundtable was facilitated by Dubois, and the meeting summary and manuscript were written by Graff and Shih, with revisions by all roundtable participants.

The abstract for this article was previously presented as a poster at the following meetings:

- Stakeholder perspectives on balancing patient-centeredness and drug costs in the design of pharmacy benefits. Presented at: Academy of Managed Care Pharmacy 27th Annual Meeting \& Expo; San Diego, California; April 8, 2015.

- Considering efficiency and fairness in the design of prescription drug benefits: seeking a balanced approach to improve patient access to medically appropriate medication and manage drug costs. Presented at: AcademyHealth Annual Research Meeting; Minneapolis, Minnesota; June 15, 2015.

Study concept and design were contributed by Shih, Dubois, and Graff, along with Barker and Dieguez. Barker and Dieguez took the lead in data collection, assisted by Graff, Shih, and Dubois. Data interpretation was performed by Shih, Larson, Sherman, and Graff, with assistance from Dubois. The manuscript was written and revised by Graff and Shih, with assistance from the other authors.

\section{ACKNOWLEDGMENTS}

Roundtable panelists and white paper authors $\left({ }^{*}\right)$ : Thomas Barker, JD* (Foley Hoag); Marc Boutin, JD (National Health Council); Doug Burgoyne, PharmD (VRx Pharmacy Services); Gabriela Dieguez, FSA, MAAA* (Milliman); Kim Dwyer, BASc (Advocate Health Care); Leslie Fish, PharmD (Fallon Community Health Plan); Mark Fendrick, MD (University of Michigan); Cliff Goodman, PhD (The Lewin Group); Alex Guerrero, PhD, JD* (University of Pennsylvania); Darin Hinderman, MT, MHA, MBA (Caterpillar); Louis Jacques, MD (ADVI); Cheryl Larson, BA (Midwest Business Group on Health); Steven D. Pearson, MD, MSc, FRCP (Institute for Clinical and Economic Review); Kenneth Schaecher, MD (SelectHealth); Helen Sherman, PharmD* (Solid Benefit Guidance); J. Russell Teagarden, DMH, MA* (Consultant); and 1 additional national payer who wished to remain anonymous. All roundtable participants received travel reimbursement and honoraria. Guerrero and Teagarden received consulting fees for participating in this study.

Additional white paper authors who did not participate in the roundtable: Ross Margulies, MPH, JD (Foley Hoag); Lynn Nishida, PharmD (Solid Benefit Guidance); and Bruce Pyenson, FSA, MAAA (Milliman).

\section{REFERENCES}

1. The Kaiser Family Foundation and Health Research \& Educational Trust. Employer Health Benefits 2016 Annual Survey. Available at: http://files. kff.org/attachment/Report-Employer-Health-Benefits-2016-Annual-Survey. Accessed December 22, 2016.

2. Choudhry NK, Bykov K, Shrank WH. Eliminating medication copayments reduces disparities in cardiovascular care. Health Aff (Millwood). 2014:33(5):863-70.

3. Gleason PP, Starner CI, Gunderson BW, Schafer JA, Sarran HS. Association of prescription abandonment with cost share for high-cost specialty pharmacy medications. J Manag Care Pharm. 2009;15(8):648-58. Available at: http://www.jmcp.org/doi/pdf/10.18553/jmcp.2009.15.8.648.

4. Goldman DP, Joyce GF, Zheng Y. Prescription drug cost sharing: associations with medication and medical utilization and spending and health. JAMA. 2007;298(1):61-69.

5. Teagarden JR, Daniels N, Sabin JE. A proposed ethical framework for prescription drug benefit allocation policy. J Am Pharm Assoc. 2003;43(1):69-74.

6. Buxbaum J, de Souza J, Fendrick AM. Using clinically nuanced cost sharing to enhance consumer access to specialty medications. Am J Manag Care. 2014;20(6):e242-44.

7. Nayak RK, Pearson SD. The ethics of 'fail first': guidelines and practical scenarios for step therapy coverage policies. Health Aff (Millwood). 2014;33(10):1779-85.

8. Chernew ME, Rosen AB, Fendrick AM. Value-based insurance design. Health Aff (Millwood). 2007;26(2):195-203. 


\section{APPENDIX Case Study Descriptions}

The 4 prototypical case studies discussed during the Variable Cost Sharing in Pharmacy Benefits Expert Stakeholder meeting are described. The case studies were meant to foster discussion of the 4 prototypical cases rather than to serve as definitive clinical examples.

\begin{tabular}{|c|c|c|c|c|}
\hline Case Study & $\begin{array}{l}\text { Dx Testing- } \\
\text { Cystic Fibrosis }\end{array}$ & $\begin{array}{l}\text { Step Therapy- } \\
\text { Rheumatoid Arthritis }\end{array}$ & $\begin{array}{c}\text { Side-Effect Tolerability- } \\
\text { Fibromyalgia }\end{array}$ & $\begin{array}{l}\text { Route/Frequency of } \\
\text { Administration- } \\
\text { Osteoporosis }\end{array}$ \\
\hline $\begin{array}{l}\text { Reason for using higher-tier/ } \\
\text { higher-cost therapy }\end{array}$ & $\begin{array}{l}\text { Biology (identified through } \\
\text { genetic testing) }\end{array}$ & $\begin{array}{l}\text { Biology (identified through } \\
\text { failed trials of initial step } \\
\text { therapy treatments) }\end{array}$ & $\begin{array}{l}\text { Patient preferences (for } \\
\text { different side-effect risks) }\end{array}$ & $\begin{array}{l}\text { Patient preferences (for route/ } \\
\text { frequency of drug adminis- } \\
\text { tration) }\end{array}$ \\
\hline Decision-maker question & $\begin{array}{l}\text { Should patients with CF } \\
\text { and the G551D mutation } \\
\text { pay higher OOP costs for } \\
\text { ivacaftor than other patients } \\
\text { with CF pay for their } \\
\text { therapy? }\end{array}$ & $\begin{array}{l}\text { Should patients with RA } \\
\text { for whom therapy with } \\
\text { oral DMARDs has failed be } \\
\text { required to pay higher OOP } \\
\text { costs for their therapy with } \\
\text { a specialty drug than other } \\
\text { patients with RA who ben- } \\
\text { efit from oral DMARDs? }\end{array}$ & $\begin{array}{l}\text { Should patients with fibro- } \\
\text { myalgia who prefer pregaba- } \\
\text { lin due to its reduced risks } \\
\text { for certain side effects be } \\
\text { required to pay higher OOP } \\
\text { costs than other patients } \\
\text { with fibromyalgia who can } \\
\text { tolerate duloxetine? }\end{array}$ & $\begin{array}{l}\text { Should patients who prefer } \\
\text { denosumab due to its reduced } \\
\text { frequency of administration } \\
\text { be required to pay higher } \\
\text { OOP costs than other patients } \\
\text { with osteoporosis who are } \\
\text { taking oral therapies? }\end{array}$ \\
\hline Disease description & $\begin{array}{l}\text { Genetic disease that causes } \\
\text { clogging of airways due to } \\
\text { mucus buildup, which can } \\
\text { lead to inflammation, } \\
\text { infection, and death }\end{array}$ & $\begin{array}{l}\text { Autoimmune disease that } \\
\text { involves inflammation at the } \\
\text { joints, resulting in pain, loss } \\
\text { of function, and disability }\end{array}$ & $\begin{array}{l}\text { Disease of unknown origin } \\
\text { characterized by chronic, } \\
\text { widespread musculoskeletal } \\
\text { pain along with fatigue, } \\
\text { sleep disturbances, emo- } \\
\text { tional distress, depression, } \\
\text { and memory loss }\end{array}$ & $\begin{array}{l}\text { Progressive bone disease } \\
\text { that results in weakened } \\
\text { bones and increased risk of } \\
\text { fractures }\end{array}$ \\
\hline Disease prevalence (U.S.) & $\begin{array}{l}\text { 30,000 children } \& \text { adults }^{1} \\
4 \%-5 \% \text { of CF population } \\
\text { has G551D mutation }{ }^{2}\end{array}$ & $\begin{array}{l}1.3 \text { million U.S. adults }{ }^{3} \\
4,489 \text { per } 1 \text { million } \\
\left(\text { commercial) }{ }^{4}\right.\end{array}$ & $\begin{array}{l}>5 \text { million Americans } 5 \\
2 \%-4 \% \text { of U.S. population } \\
(3.4 \% \text { in women } \& 0.5 \% \text { in } \\
\text { men })^{5}\end{array}$ & $\begin{array}{l}10.2 \text { million adults }{ }^{6} \\
5.1 \% \text { for ages } 50-59 \\
8.0 \% \text { for ages } 60-69\end{array}$ \\
\hline Disease cost impact & $\begin{array}{l}\text { Annual health care cost } \\
\text { per patient (excluding pre- } \\
\text { scription drugs): } \$ 29,000 \text { - } \\
\$ 40,000^{7} \\
\text { Inpatient hospital costs: } \\
\$ 22,000-\$ 23,000 \\
\text { annually }\end{array}$ & $\begin{array}{l}\text { Annual health care cost } \\
\text { per patient: } \$ 9,417(\$ 2,284 \\
\text { inpatient hospitalization } \& \\
\$ 3,252 \text { prescription drugs })^{8} \\
\text { Employer impact: Employed } \\
\text { persons with RA lost a } \\
\text { median of } 39 \text { workdays per } \\
\text { year. } 9,10\end{array}$ & $\begin{array}{l}\text { Annual health care cost } \\
\text { per patient: } \$ 9,531 \text { ( } 25 \% \\
\text { inpatient, } 11 \% \text { prescription } \\
\text { drugs) } \\
\text { Employer impact: } \\
\text { Employees with FM are } \\
\text { more likely to file a dis- } \\
\text { ability claim than employees } \\
\text { without FM ( } 45 \% \text { vs. } 22 \%)^{12}\end{array}$ & $\begin{array}{l}\text { Annual health care cost } \\
\text { of fractures per patient: } \\
\$ 8,600^{13} \\
\text { More than } 1.5 \text { million frac- } \\
\text { tures per year attributed to } \\
\text { osteoporosis }{ }^{14} \\
\text { Cost of care expected to rise } \\
\text { to } \$ 25.3 \text { billion by } 2025^{15}\end{array}$ \\
\hline $\begin{array}{l}\text { Drug therapy alternatives by } \\
\text { tier (estimated annual cost, } \\
\text { administration, \& frequency) }\end{array}$ & $\begin{array}{l}\text { Specialty tier: } \\
\text { ivacaftor (Kalydeco): } \\
\$ 300,000^{16} \text {-oral, daily } \\
\text { Tiers } 1 / 2 \text { : } \\
\text { "Standard therapies" } \\
\text { dornase alfa (Pulmozyme), } \\
\text { antibiotics, nonsteroidal } \\
\text { anti-inflammatory drugs } \\
\text { (NSAIDs) — } \$ 20,000^{7} \\
\text { dornase alfa (Pulmozyme): } \\
\$ 14,000^{17} \text { —oral, daily }\end{array}$ & $\begin{array}{l}\text { Specialty tier: } \\
\text { Specialty drugs (abatacept } \\
\text { [Orencia], adalimumab } \\
\text { [Humira], anakinra [Kineret], } \\
\text { certolizumab pegol [Cimzia], } \\
\text { etanercept [Enbrel], golim- } \\
\text { umab [Simponi], infliximab } \\
\text { [Remicade], rituximab } \\
\text { [Rituxan], tocilizumab } \\
\text { [Actemra]): } \$ 18,000^{4}- \\
\text { injection, weekly to monthly } \\
\text { tofacitinib citrate (Xeljanz) - } \\
\text { oral, daily } \\
\text { Tier 1: } \\
\text { Oral DMARDs (hydroxy- } \\
\text { chloroquine, leflunomide, } \\
\text { MTX, sulfasalazine): } \$ 120- \\
\text { oral, daily }\end{array}$ & $\begin{array}{l}\text { Tiers 2/3: } \\
\text { pregabalin (Lyrica), milnacip- } \\
\text { ran (Savella): } \$ 1,300^{18}- \\
\text { oral, daily } \\
\text { Tier 1: } \\
\text { duloxetine: } \$ 100 \\
\text { (assumed) - oral, daily }\end{array}$ & $\begin{array}{l}\text { Specialty tier: } \\
\text { denosumab (Prolia): } \\
\$ 1,650^{19} \text { _injection, twice } \\
\text { per year } \\
\text { Tier } 1 \text { : } \\
\text { bisphosphonates: } \$ 100^{19} \text { _ } \\
\text { oral, daily to monthly }\end{array}$ \\
\hline
\end{tabular}




\begin{tabular}{|c|c|c|c|c|}
\hline Case Study & $\begin{array}{l}\text { Dx Testing- } \\
\text { Cystic Fibrosis }\end{array}$ & $\begin{array}{c}\text { Step Therapy- } \\
\text { Rheumatoid Arthritis }\end{array}$ & $\begin{array}{c}\text { Side-Effect Tolerability- } \\
\text { Fibromyalgia }\end{array}$ & $\begin{array}{c}\text { Route/Frequency of } \\
\text { Administration- } \\
\text { Osteoporosis }\end{array}$ \\
\hline Evidence on outcomes & $\begin{array}{l}\text { Ivacaftor is FDA approved } \\
\text { for CF based on studies } \\
\text { showing improvement } \\
\text { with ivacaftor vs. standard } \\
\text { therapy. }{ }^{20-22} \\
\text { No evidence on long-term } \\
\text { outcomes }\end{array}$ & $\begin{array}{l}\text { All the above medications } \\
\text { are FDA approved for treat- } \\
\text { ment of patients with RA } \\
\text { (including patients who } \\
\text { have failed therapy with } \\
\text { MTX and have been shown } \\
\text { to be effective against pla- } \\
\text { cebo). }{ }^{23}\end{array}$ & $\begin{array}{l}\text { Three drugs approved by } \\
\text { the FDA to treat FM: pre- } \\
\text { gabalin (Lyrica), duloxetine } \\
\text { (Cymbalta), and milnacipran } \\
\text { (Savella). All have demon- } \\
\text { strated improved outcomes } \\
\text { vs. placebo. } \\
\text { No head-to-head clinical } \\
\text { trials } \\
\text { Similar outcomes for the } 3 \\
\text { FDA-approved drugs } \\
\text { (e.g., } 30 \% \text { pain relief) } 24 \\
\text { Adverse events: } \\
\text { Evidence that pregabalin } \\
\text { has lower risks of diarrhea, } \\
\text { headache, and nausea } 24\end{array}$ & $\begin{array}{l}\text { All the above medications } \\
\text { are FDA approved for the } \\
\text { treatment and/or prevention } \\
\text { of osteoporosis in postmeno- } \\
\text { pausal women. }{ }^{25} \\
\text { Clinical trials demonstrate } \\
\text { improved outcomes with } \\
\text { denosumab vs. placebo. } 26,27 \\
\text { Limited evidence on deno- } \\
\text { sumab vs. bisphosphonates. } \\
\text { One RCT comparing deno- } \\
\text { sumab and alendronate in } \\
\text { postmenopausal women } \\
\text { with low bone mass con- } \\
\text { cluded that patients taking } \\
\text { denosumab had significantly } \\
\text { increased bone mineral den- } \\
\text { sity. No difference found in } \\
\text { adverse events. }{ }^{28} \\
\text { Adverse events: } \\
\text { bisphosphonates: GI prob- } \\
\text { lems, renal dysfunction, } \\
\text { and joint/muscle pain. } \\
\text { denosumab: skin rash, } \\
\text { infection, and hypocalcemia }\end{array}$ \\
\hline Guidelines/recommendations & $\begin{array}{l}\text { Cystic Fibrosis Foundation: } \\
\text { Pulmonary Clinical Practice } \\
\text { Guideline Committee } \\
\text { recommends ivacaftor for } \\
\text { patients with CF } \geq 6 \text { years \& } \\
\text { with G551D mutation. }{ }^{29}\end{array}$ & $\begin{array}{l}\text { American College } \\
\text { of Rheumatology: } \\
\text { Recommends the use of } \\
\text { biologics after failure of oral } \\
\text { DMARDs and for rapidly } \\
\text { progressing disease. } 30\end{array}$ & None found & $\begin{array}{l}\text { National Osteoporosis } \\
\text { Foundation: Silent on the use } \\
\text { of denosumab vs. } \\
\text { bisphosphonates }^{31}\end{array}$ \\
\hline Other contextual factors & $\begin{array}{l}\text { Life expectancy of } 37-40 \\
\text { years of age }^{1} \\
\text { Cardiopulmonary complica- } \\
\text { tions account for } 85 \% \text { of CF } \\
\text { deaths. }{ }^{32}\end{array}$ & $\begin{array}{l}86.8 \% \text { of patients with RA } \\
\text { treated with any drug } \\
35.5 \% \text { of patients with RA } \\
\text { treated with specialty drug }\end{array}$ & $\begin{array}{l}82 \% \text { of patients on mono- } \\
\text { therapy ( } 21 \% \text { pregabalin, } \\
20 \% \text { duloxetine, } 10 \% \\
\text { milnacipran) }\end{array}$ & $\begin{array}{l}\text { Preferences: There is evidence } \\
\text { that patients with osteoporo- } \\
\text { sis have different preferences } \\
\text { for the attributes of their drug } \\
\text { therapy. }{ }^{34,35} \text { One discrete } \\
\text { choice experiment found that } \\
\text { patients preferred a } 6 \text {-month } \\
\text { subcutaneous injection over } \\
\text { weekly oral tablets, and } \\
\text { disliked being at risk for gas- } \\
\text { trointestinal disorders more } \\
\text { than being at risk for skin } \\
\text { reactions. } 35 \\
\text { Adherence rates: Greater } \\
\text { adherence rates with } 6 \text {-month } \\
\text { injection than with once- } \\
\text { weekly tablet }{ }^{36}\end{array}$ \\
\hline $\begin{array}{l}\text { Potential ethical } \\
\text { considerations }\end{array}$ & $\begin{array}{l}\text { Distribution of costs based } \\
\text { on differences in biology }\end{array}$ & $\begin{array}{l}\text { "Good soldier" argument- } \\
\text { Patients for whom initial } \\
\text { step therapy requirements } \\
\text { have failed and now would } \\
\text { like to attempt treatment } \\
\text { with a higher-cost } \\
\text { medication }\end{array}$ & $\begin{array}{l}\text { Role of preferences in defin- } \\
\text { ing meaningful health out- } \\
\text { comes? } \\
\text { Impact on health outcomes? }\end{array}$ & $\begin{array}{l}\text { Impact of preferences on } \\
\text { adherence rates and health } \\
\text { outcomes }\end{array}$ \\
\hline
\end{tabular}

CF= cystic fibrosis; DMARD = disease-modifying antirheumatic drug; DX=diagnosis; FDA =U.S. Food and Drug Administration; FM=fibromyalgia; GI = gastrointestinal; $M T X=$ methotrexate; $O O P=$ out - of - pocket cost $R C T=$ randomized controlled trial; $R A=$ rheumatoid arthritis 


\section{Does a One-Size-Fits-All Cost-Sharing Approach Incentivize Appropriate Medication Use? A Roundtable on the Fairness and Ethics Associated with Variable Cost Sharing}

\section{APPENDIX Case Study Descriptions (continued)}

\section{APPENDIX REFERENCES}

1. O'Sullivan BP, Freedman SD. Cystic fibrosis. Lancet. 2009;373(9678):1891-904.

2. McKone EF, Emerson SS, Edwards KL, Aitken ML. Effect of genotype on phenotype and mortality in cystic fibrosis: a retrospective cohort study. Lancet. 2003;361(9370):1671-76.

3. Kavanaugh A. Economic consequences of established rheumatoid arthritis and its treatment. Best Pract Res Clin Rheumatol. 2007;21(5):929-42.

4. Gleason PP, Alexander GC, Starner CI, et al. Health plan utilization and costs of specialty drugs within 4 chronic conditions. J Manag Care Pharm. 2013;19(7):542-48. Available at: http://www.jmcp.org/doi/pdf/10.18553/ jmcp.2013.19.7.542.

5. Lawrence RC, Felson DT, Helmick CG, et al. Estimates of the prevalence of arthritis and other rheumatic conditions in the United States. Part II. Arthritis Rheum. 2008;58(1):26-35.

6. Wright NC, Looker AC, Saag KG, et al. The recent prevalence of osteoporosis and low bone mass in the United States based on bone mineral density at the femoral neck or lumbar spine. J Bone Miner Res. 2014;29(11):2520-26. 7. O'Sullivan AK, Sullivan J, Higuchi K, Montgomery AB. Health care utilization \& costs for cystic fibrosis patients with pulmonary infections. Manag Care. 2011;20(2):37-44.

8. Simons WR, Rosenblatt LC, Trivedi DN. The economic consequences of rheumatoid arthritis: analysis of Medical Expenditure Panel Survey 2004, 2005, and 2006 data. J Occup Environ Med. 2012;54(1):48-55.

9. Burton W, Morrison A, Maclean R, Ruderman E. Systematic review of studies of productivity loss due to rheumatoid arthritis. Occup Med (Lond). 2006;56(1):18-27.

10. Birnbaum H, Pike C, Kaufman R, Marynchenko M, Kidolezi Y, Cifaldi M. Societal cost of rheumatoid arthritis patients in the U.S. Curr Med Res Opin. 2010;26(1):77-90

11. Berger A, Dukes E, Martin S, Edelsberg J, Oster G. Characteristics and healthcare costs of patients with fibromyalgia syndrome. Int J Clin Pract. 2007;61(9):1498-508

12. Robinson RL, Birnbaum HG, Morley MA, Sisitsky T, Greenberg PE, Claxton AJ. Economic cost and epidemiological characteristics of patients with fibromyalgia claims. J Rheumatol. 2003;30(6):1318-25.

13. Blume SW, Curtis JR. Medical costs of osteoporosis in the elderly Medicare population. Osteoporos Int. 2011;22(6):1835-44.

14. Keen RW. Burden of osteoporosis and fractures. Curr Osteoporos Rep. 2003;1(2):66-70.

15. Burge R, Dawson-Hughes B, Solomon DH, Wong JB, King A, Tosteson A. Incidence and economic burden of osteoporosis-related fractures in the United States, 2005-2025. J Bone Miner Res. 2007;22(3):465-75.

16. Barrett PM, Alagely A, Topol EJ. Cystic fibrosis in an era of genomically guided therapy. Hum Mol Genet. 2012;21(R1):R66-71.

17. Cystic Fibrosis Foundation. Pulmozyme inhalation solution. Available at: http://cysticfibrosis.about.com/od/treatment/p/pulmozyme.htm. Accessed December 25, 2016.

18. Lloyd A, Boomershine CS, Chandran A, Zlateva G. The cost-effectiveness of pregabalin in the treatment of fibromyalgia: U.S. perspective. J Med Econ. 2012;15(3):481-92

19. Parthan A, Kruse M, Yurgin N, Huang J, Viswanathan HN, Taylor D. Cost effectiveness of denosumab versus oral bisphosphonates for postmenopausal osteoporosis in the U.S. Appl Health Econ Health Policy. 2013;11(5):485-97.

20. Accurso FJ, Rowe SM, Clancy JP, et al. Effect of VX-770 in persons with cystic fibrosis and the G551D-CFTR mutation. N Engl J Med. 2010;363(21):1991-2003

21. Ramsey BW, Davies J, McElvaney NG, et al. A CFTR potentiator in patients with cystic fibrosis and the G551D mutation. N Engl J Med. 2011;365(18):1663-72.

22. Davies JC, Wainwright CE, Canny GJ, et al. Efficacy and safety of ivacaftor in patients aged 6 to 11 years with cystic fibrosis with a G551D mutation. Am J Respir Crit Care Med. 2013;187(11):1219-25.
23. Donahue KE, Jonas DE, Hansen RA, et al. Drug therapy for rheumatoid arthritis in adults: an update. Comparative Effectiveness Reviews, No. 55. (Prepared by RTI-UNC Evidence-based Practice Center under Contract No. 290-02-0016-I.) Rockville, MD: Agency for Healthcare Research and Quality (U.S.); April 2012. Available at: https://www.effectivehealthcare.ahrq.gov/ search-for-guides-reviews-and-reports/?pageaction=displayproduct\&product id=1042. Accessed December 25, 2016.

24. Hauser W, Petzke F, Sommer C. Comparative efficacy and harms of duloxetine, milnacipran, and pregabalin in fibromyalgia syndrome. J Pain. 2010;11(6):505-21.

25. Crandall CJ, Newberry SJ, Diamant A, et al. Treatment to prevent fractures in men and women with low bone density or osteoporosis: update of a 2007 report. Comparative Effectiveness Reviews, No. 53. (Prepared by Southern California Evidence-based Practice Center under Contract No. HHSA-290-2007-10062-I). Rockville, MD: Agency for Healthcare Research and Quality (U.S.); March 2012. Available at: https://www.effectivehealthcare.ahrq.gov/ehc/products/160/1007/CER53_LowBoneDensity_ FinalReport_20120823.pdf. Accessed December 25, 2016.

26. Bone HG, Bolognese MA, Yuen CK, et al. Effects of denosumab on bone mineral density and bone turnover in postmenopausal women. J Clin Endocrinol Metab. 2008;93(6):2149-57.

27. Cummings SR, San Martin J, McClung MR, et al. Denosumab for prevention of fractures in postmenopausal women with osteoporosis. N Engl J Med. 2009;361(8):756-65.

28. Brown JP, Prince RL, Deal C. Comparison of the effect of denosumab and alendronate on BMD and biochemical markers of bone turnover in postmenopausal women with low bone density: a randomized, blinded, phase 3 trial. J Bone Miner Res. 2009;24(1):153-61.

29. Mogayzel PJ Jr, Naureckas ET, Robinson KA, et al. Cystic fibrosis pulmonary guidelines: chronic medications for maintenance of lung health Am J Respir Crit Care Med. 2013;187(7):680-89.

30. Singh JA, Furst DE, Bharat A, et al. 2012 update of the 2008 American College of Rheumatology recommendations for the use of disease-modifying antirheumatic drugs and biologic agents in the treatment of rheumatoid arthritis. Arthritis Care Res. 2012;64(5):625-39.

31. National Osteoporosis Foundation. Clinician's Guide to Prevention and Treatment of Osteoporosis. Washington, DC: National Osteoporosis Foundation; 2014.

32. Cystic Fibrosis Foundation. Cystic Fibrosis Foundation patient registry, 2006. Annual data report to the center directors. 2008. Bethesda, MD.

33. Dussias P, Kalali AH, Staud RM. Treatment of fibromyalgia. Psychiatry. 2010;7(5):15-18

34. Silverman S, Calderon A, Kaw K, et al. Patient weighting of osteoporosis medication attributes across racial and ethnic groups: a study of osteoporosis medication preferences using conjoint analysis. Osteoporos Int. 2013;24(7):2067-77.

35. Hiligsmann M, Dellaert BG, Dirksen CD, et al. Patients' preferences for osteoporosis drug treatment: a discrete-choice experiment. Arthritis Research E Therapy. 2014;16(1):R36

36. Freemantle N, Satram-Hoang S, Tang ET, et al. Final results of the DAPS (Denosumab Adherence Preference Satisfaction) study: a 24-month, randomized, crossover comparison with alendronate in postmenopausal women. Osteoporos Int. 2012;23(1):317-26. 